\title{
PENGARUH PEMBATASAN PAKAN DAN SUMBER SERAT KASAR BERBEDA TERHADAP BOBOT HIDUP, BOBOT KARKAS DAN POTONGAN KOMERSIAL KARKAS AYAM BROILER STRAIN LOHMAN
}

\author{
Yolanda S. Mait, J.E.G. Rompis*, B. Tulung, J. Laihad, J.J.M.R. Londok
}

Fakultas Peternakan, Universitas Sam Ratulangi Manado, 95115

\begin{abstract}
ABSTRAK
Penelitian ini bertujuan untuk mengetahui pengaruh pembatasan pakan dengan sumber serat kasar berbeda terhadap bobot hidup, bobot karkas dan potongan komersial ayam broiler strain Lohman. Materi yang digunakan 24 ekor ayam broiler. Rancangan yang digunakan adalah Rancangan Acak Lengkap (RAL) pola faktorial $2 \times 4$ dengan 3 ulangan. Pembatasan pakan dilakukan pada umur 21 sampai 28 hari, sesudah pembatasan ayam broiler diberikan pakan komersial ad libitum sampai masa panan (42 hari). Sebagai faktor A (pembatasan pakan) dengan taraf faktor A0 (tanpa pembatasan), dan A1 (pembatasan 20\%). Faktor B (sumber serat kasar bahan pakan) dengan taraf faktor B0 (pakan komersial), B1 (pakan komersial dengan kulit kopi), B2 (pakan komersial dengan dedak padi), dan B3 (pakan komersial dengan ampas kelapa). Untuk peubah yang berbeda nyata dilanjutkan dengan uji BNJ. Peubah yang diukur adalah bobot hidup, bobot karkas dan potongan komersial yang terdiri atas persentase dada, paha atas, paha bawah, sayap dan punggung. Anova menunjukkan bahwa kombinasi perlakuan memberikan pengaruh berbeda nyata $(\mathrm{P}<0,05)$ terhadap bobot hidup, bobot karkas dan potongan komersial ayam broiler strain Lohman. Pembatasan pakan 20\% dengan ampas
\end{abstract}

Kata Kunci: Potongan komersial Pembatasan Pakan, Serat Kasar,

*Korespondensi Corresponding author) : email: jegronne@yahoo.co.id kelapa sebagai pakan sumber serat memberikan hasil yang baik terhadap bobot hidup, bobot karkas dan potongan komersial ayam broiler strain Lohman

\section{ABSTRACT}

THE EFFECT OF FEED RESTRICTION AND DIFFERENCE SOURCE OF CRUDE FIBER ON LIVE WEIGT, CARCASS WEIGHT AND COMMERCIAL PIECES OF BROILER WITH LOHMAN STRAIN. The objective of research was to determine the effect of feed restriction and source of different crude fiber on live weight, carcass weigth and commercial pieces of broiler with Lohman strain. The material used was 24 broilers. This research was using a Completely Randomized Design (CRD) in Factorial pattern of $2 \times 4$ with 3 replications. Feed restrictions were carried out at the age of 21 to 28 days old, after restrictions on broilers were fed commercial ration ad libitum feed until a time periode of 42 days. As a factor $\mathrm{A}$ was restricted feeding consisted of without restrictions (A0), and 20 percents restricted ration (A1). A factor $\mathrm{B}$ was source of crude fiber consisted of commercial feed (B0), commercial feed with coffee hull meal (B1), commercial feed with rice bran (B2), and commercial feed with coconut pulp (B3). The data analyzed used variance analysis and Tukey test to determine which one of treatment was significantly different from each other. The variables measured were live weight, carcass weight and percentage of commercial pieces consist of breast, thigh, drumstick, wing and brisket. The results 
showed that the combination treatment of feed restriction and source of crude fiber in feed gave a very significant different effect $(\mathrm{P}<0.05)$ on live weigth, carcass weight and commercial pieces of broiler with Lohman strain. The 20 percents restriction feeding with coconut pulp as a source of crude fiber gave best results on live weight, carcass weight, and commercial pieces of broiler with Lohman strain.

Keywords: Feed restriction, crude fiber source, broiler commercial pieces

\section{PENDAHULUAN}

Ayam broiler (pedaging) merupakan jenis ternak yang dikembangkan sebagai sumber pemenuhan kebutuhan protein hewani, memiliki daging yang empuk, ukuran badan yang besar, tingkat efisiensi pakan yang tinggi dan pertambahan bobot badan sangat cepat. Strain merupakan salah satu bagian dari pengaruh faktor genetik, strain lohman berasal dari ayam kelas inggris yang memiliki bentuk badan padat dan memiliki daging persentase karkas yang tinggi, cakar kaki besar tidak berbulu dan berwana kuning.

Pembatasan pakan (restricted feeding) merupakan salah satu upaya yang dilakukan untuk mengurangi dampak akibat konsumsi pakan berlebihan pada sistem pemberian ad libitum. Kusuma et al. (2016) menyatakan bahwa pembatasan pakan merupakan program untuk memberikan pakan pada ternak sesuai dengan kebutuhan hidup pokok, dengan tujuan meningkatkan efisiensi penggunaan pakan dan penurunan lemak tubuh. Menurut Londok et al. (2012) dalam penelitian pembatasan pakan $10 \%$ dan $20 \%$ yang diberikan selama 7 hari, pembatasan pakan 20\% dapat meningkatkan berat badan, mempengaruhi efisiensi penggunaan pakan dan mampu memperbaiki kualitas karkas dibandingkan pemberian pakan ad libitum. Tulung et al. (2015), menyatakan bahwa pemberian serat kasar $10 \%$ dalam ransum dengan pemberian selama 16 hari menurunkan bobot karkas dan lemak abdomen. Toleransi broiler terhadap lamanya pemberian pembatasan pakan hanya sampai 8 hari dengan kadar serat kasar sebesar $10 \%$. Serat merupakan senyawa karbohidrat yang sulit dicerna oleh ternak monogastri, namun berfungsi untuk mengatur kerja usus, mempercepat laju digesta dan memacu perkembangan organ pencernaan. Pakan lokal sumber serat berasal dari limbah agroindusti yang mudah di dapat namun memiliki kandungan nutrisi yang baik dan harganya murah yaitu kulit kopi, dedak padi dan ampas kelapa. Jenis pakan dapat mempengaruhi kualitas dan kuantitas karkas, untuk itu penyusunan dan pemilihan bahan pakan yang tepat harus diperhatikan.

Konsumen memiliki keinginan yang berbeda-beda dalam memilih potongan 
bagian daging yang diinginkan membuat peternak harus memperhatikan kualitas karkas yang akan dihasilkan. Potongan komersial dibagi menjadi beberapa bagian, yaitu bagian dada (breast), paha atas (thigh), paha bawah (drumstik), sayap (wing) dan punggung (brisket). Mahmood et al. (2007) menyatakan bahwa pembatasan pakan tidak mempunyai dampak yang buruk terhadap karakteristik karkas yang dihasilkan. Pembatasan pakan diharapkan dapat meningkatkan produksi karkas. Serat kasar berfungsi untuk mengatur kerja usus dan dapat menurunkan kadar lemak dalam karkas broiler.

Berdasarkan uraian di atas, telah dilakukan penelitian dengan tujuan untuk mengetahui Pengaruh Pembatasan Pakan dan Sumber Serat Kasar Bahan Pakan terhadap Bobot Hidup, Bobot Karkas dan Potongan Komersial Ayam Broiler Strain Lohman.

\section{MATERI DAN METODE PENELITIAN}

Penelitian ini menggunakan 24 ekor broiler strain Lohman umur 6 minggu dari PT. Japfa Comfeed Indonesia dengan bobot badan \pm 2400 gram. Kandang sistem baterei 24 unit dengan ukuran $30 \times 40 \times 60 \mathrm{~cm}^{3}$ per unit, setiap unit berisi 2 ekor ayam broiler. Peralatan yang digunakan tempat pakan, tempat minum, lampu, timbangan, kipas angin, sapu dan tempat sampah. Bahan pakan: pakan komersial BR 21-E, kulit kopi, dedak padi, ampas kelapa dan tepung ikan. Komposisi pakan dapat dilihat pada Tabel 2. Formulasi pakan mengacu pada kebutuhan broiler PT. Japfa Comfeed Indonesia. Perlakuan pembatasan pakan dan sumber serat kasar berbeda diberikan pada ayam broiler selama 8 hari (umur 21 sampai 28 hari) kemudian diberikan pakan komersial ad libitum sampai masa panen (42 hari).

Penelitian ini menggunakan Rancangan Acak Lengkap (RAL) pola Faktorial $2 \times 4$ dengan 3 ulangan (Kusriningrum, 2010). Faktor A (pembatasan pakan): A0 (tanpa pembatasan), dan A1 (pembatasan 20\%), Faktor B (sumber serat kasar berbeda): B0 (kontrol), B1 (pakan komersial dengan kulit kopi), B2 (pakan komersial dengan dedak padi), dan B3 (pakan komersial dengan ampas kelapa). Jika terdapat interaksi antar kombinasi perlakuan dilanjutkan dengan uji Beda Nyata Jujur (BNJ).

\section{Prosedur Pemotongan (Nugraheni, 2013).}

Ayam broiler dipuasakan \pm 8 jam kemudian ditimbang. Kemudian disembelih/dipotong pada vena jugularis dan arteri karotis didasar rahang. Penuntasan darah dilakukan dengan cara menggantung broiler pada gantungan. Pencelupan dalam air panas suhu $71-82^{\circ} \mathrm{C}$ 
selama 45-60 detik. Dilanjutkan dengan pemotongan kaki dan pengeluaran jeroan. Pemotongan komersial meliputi dada, sayap, paha, dan punggung. Potongan komersial dada diperoleh dengan cara memotong daerah scapula sampai bagian sterium, sayap diperoleh dengan cara memotong daerah persendian antara lengan atas dan scapula. Paha didapatkan dengan memotong daerah persendian femur dengan tibia, dan punggung didapatkan dengan memotong pada tulang leher hingga buntut. Selanjutnya penimbangan potonganpotongan karkas, pengemasan atau pengepakan.

Tabel 1. Komposisi Bahan Pakan Perlakuan

\begin{tabular}{lccccccc}
\hline \multirow{2}{*}{ Bahan Pakan } & BK & Protein & LK & SK & Ca & P & EM \\
\cline { 2 - 7 } & $(\%)$ & $(\%)$ & $(\%)$ & $(\%)$ & $(\%)$ & $(\%)$ & Kkal/kg \\
\hline BR 21-F* & 88,00 & 22,00 & 6,00 & 5,00 & 1,05 & 0,85 & 3135,00 \\
K. Kopi** & 88,69 & 16,72 & 7,06 & 20,02 & 0,23 & 0,02 & 3063,00 \\
Dedak*** & 85,59 & 7,91 & 5,91 & 23,37 & 0,22 & 0,95 & 2788,50 \\
A.Kelapa**** & 88,69 & 11,35 & 23,36 & 14,97 & 0,11 & 0,47 & 3279,75 \\
T. Ikan*** & 92,16 & 56,91 & 9,34 & 0,09 & 7,04 & 3,67 & 3851,80 \\
\hline
\end{tabular}

Ket: $\mathrm{BK}=$ bahan kering, $\mathrm{LK}=$ lemak kasar, $\mathrm{SK}=$ serat kasar, $\mathrm{Ca}=$ kalsium, $\mathrm{P}=$ fosfor, $\mathrm{EB}=$ energi bruto, $\mathrm{BR}$ 21-E = pakan komersial (Lohman). Londok et al., (2018)*, Tulung, et al. (2015)**, Londok (2018)***, Novita.(2012)****

Tabel 2. Susunan Pakan Perlakuan, Komposisi Zat-Zat Makanan dan Energi Metabolis

\begin{tabular}{lcccc}
\hline \multirow{2}{*}{ Bahan Pakan } & \multicolumn{4}{c}{ Perlakuan } \\
\cline { 2 - 5 } & B0 & B1 & B2 & B3 \\
\hline BR 21-F & 100 & 65 & 62 & 41 \\
Kulit Kopi & 0 & 35 & 0 & 0 \\
Dedak Padi & 0 & 0 & 31 & 0 \\
Ampas Kelapa & 0 & 0 & 0 & 50 \\
Tepung Ikan & 0 & 0 & 7 & 9 \\
\hline \multicolumn{1}{c}{ Total } & $\mathbf{1 0 0}$ & $\mathbf{1 0 0}$ & $\mathbf{1 0 0}$ & $\mathbf{1 0 0}$ \\
\hline \multicolumn{1}{c}{ Kandungan zat-zat makanan dan Energi } & & & \\
Bahan kering (\%) & 88,00 & 88,24 & 87,54 & 88,72 \\
Protein (\%) & 22,00 & 20,15 & 20,08 & 19,82 \\
Lemak (\%) & 6,00 & 6,37 & 6,21 & 14,98 \\
Serat kasar (\%) & 5,00 & 10,26 & 10,41 & 9,62 \\
Kalsium (\%) & 1,05 & 0,76 & 1,21 & 1,12 \\
Fosfor (\%) & 0,85 & 0,56 & 1,08 & 0,91 \\
Energi metabolisme (kkal/kg) & 3135 & 3110 & 3078 & 3272 \\
\hline
\end{tabular}

Ket: dihitung berdasarkan Tabel 1. 


\section{Peubah yang diukur dalam penelitian ini:}

1. Bobot hidup diperoleh dengan penimbangan bobot badan umur 42 hari

2. Bobot karkas diperoleh setelah ayam bersih dari bulu, isi perut, kepala dan darah.

3. Potongan komersial diperoleh dengan cara memotong bagian-bagian tubuh, menjadi potongan komersial (5 bagian) yaitu dada, paha atas, paha bawah, sayap dan punggung, (Markley et al., 1980).

- Persentase Dada $\%$ dada $=\frac{\text { bobot dada }(\mathrm{g})}{\text { bobot karkas }(\mathrm{g})} \times 100$

- Persentase paha atas dan bawah $\%$ paha atas $\frac{\text { bobot paha atas }(\mathrm{g})}{\text { bobot karkas }(\mathrm{g})} \times 100$ $\%$ paha bawah $\frac{\text { bobot paha bawah }(\mathrm{g})}{\text { bobot karkas }(\mathrm{g})} \mathrm{x} 100$

- Persentase Sayap $\%$ sayap $=\frac{\text { bobot } \operatorname{sayap}(g)}{\text { bobot } \text { karkas }(g)} \times 100$

- Persentase Punggung $\%$ punggung $=\frac{\text { bobot punggung }(\mathrm{g})}{\text { bobot karkas }(\mathrm{g})} \times 100$

\section{HASIL DAN PEMBAHASAN}

Data hasil penelitian tentang pengaruh pembatasan pakan dan sumber serat kasar berbeda terhadap potongan komersial ayam broiler starin Lohman dapat dilihat pada Tabel 3.

\section{Pengaruh Perlakuan terhadap Bobot Hidup}

Rataan bobot hidup berkisar antara 2168,67 sampai 2646,00 gram (Tabel 3). Hasil penelitian ini berada pada kisaran normal sesuai yang direkomendasikan untuk strain Lohman dengan bobot hidup pada minggu keenam sebesar 2392 gram (Lohman Meat, 2007). Anova menunjukkan bahwa interaksi antara kombinasi perlakuan pembatasan pakan dan pemberian sumber serat kasar berbeda memberikan pengaruh yang nyata $(\mathrm{P}<0,05)$ terhadap bobot hidup ayam broiler. Uji BNJ menunjukkan bahwa bobot hidup ayam broiler yang mendapatkan kombinasi perlakuan A0B3 sama dengan A0B2, namun berbeda nyata $(\mathrm{P}<0,05)$ dengan kombinasi perlakuan A1B2, A1B3, A0B0. A1B2 sama dengan A1B3, A0B0 namun berbeda nyata $(\mathrm{P}<0,05)$ dengan $\mathrm{A} 0 \mathrm{~B} 1$, A1B0, A1B1 terhadap bobot hidup. Kombinasi perlakuan A0B1 sama dengan A1B0, namun berbeda nyata $(\mathrm{P}<0,05)$ dengan A1B1 terhadap bobot hidup. Kombinasi perlakuan A1B0 sama dengan A1B1 terhadap bobot hidup. Rendahnya persentase karkas yang mendapatkan kombinasi perlakuan A1B0 karena dalam kulit kopi mengandung zat anti nutrisi tannin dan kafein. Purawisastra (2001) dan Yamin (2008) menyatakan bahwa, ampas kelapa mengandung galaktomanan sebesar 61\%. Akmal dan Filawati (2008) bahwa dalam kulit kopi mengandung serat kasar serta zat anti nutrisi seperti tanin dan kafein. 
Tabel 3. Rataan Bobot Hidup, Bobot Karkas dan Persentase Potongan Komersial Karkas Ayam Broiler Strain Lohman.

\begin{tabular}{|c|c|c|c|c|c|c|}
\hline \multirow{2}{*}{ Peubah } & \multirow{2}{*}{ Faktor A } & \multicolumn{4}{|c|}{ Faktor B } & \multirow{2}{*}{ Rataan } \\
\hline & & B0 & B1 & B2 & B3 & \\
\hline \multirow{6}{*}{$\begin{array}{l}\text { Bobot hidup } \\
\quad \text { (gram) }\end{array}$} & \multirow{2}{*}{ A0 } & 2448,00 & 2274,67 & 2572,67 & 2646,00 & 2485,3 \\
\hline & & $\pm 19,92^{\mathrm{b}}$ & $\pm 17,90^{\mathrm{c}}$ & $\pm 27,06^{\mathrm{a}}$ & $\pm 25,24^{\mathrm{a}}$ & $3 \pm 162,50$ \\
\hline & \multirow[b]{2}{*}{ A1 } & 2256,00 & 2168,67 & 2460,67 & 2448,67 & 2333,50 \\
\hline & & $\pm 33,42^{\text {cd }}$ & $\pm 37,81^{\text {cd }}$ & $\pm 19,66^{\mathrm{b}}$ & $\pm 11,15^{\mathrm{b}}$ & $\pm 144,47$ \\
\hline & \multirow{2}{*}{ Rataan } & 2352,00 & 2221,67 & 2516,67 & 2547,33 & 2409,42 \\
\hline & & $\pm 135,76$ & $\pm 74,95$ & $\pm 79,20$ & $\pm 139,54$ & $\pm 107,36$ \\
\hline \multirow{6}{*}{$\begin{array}{c}\text { Bobot } \\
\text { Karkas } \\
\text { (gram) }\end{array}$} & \multirow{2}{*}{ A0 } & 2155,33 & 1853,00 & 2145,00 & 2232,00 & 2096,58 \\
\hline & & $\pm 23,71^{\mathrm{a}}$ & $\pm 25,36^{\mathrm{e}}$ & $\pm 23,64^{\mathrm{ab}}$ & $\pm 12,53^{\mathrm{a}}$ & $\pm 166,45$ \\
\hline & \multirow{2}{*}{ A1 } & 1863,67 & 1746,00 & 1975,00 & 2069,33 & 1913,50 \\
\hline & & $\pm 21,39^{\mathrm{e}}$ & $\pm 25,94^{\mathrm{f}}$ & $\pm 21,07^{\mathrm{d}}$ & $\pm 22,50^{\mathrm{bc}}$ & $\pm 139,77$ \\
\hline & \multirow{2}{*}{ Rataan } & 2008,00 & 1799,50 & 2060,00 & 2150,67 & 2004,54 \\
\hline & & $\pm 204,12$ & $\pm 75,66$ & $\pm 120,21$ & $\pm 115,02$ & $\pm 128,75$ \\
\hline \multirow{6}{*}{$\begin{array}{c}\text { Persentase } \\
\text { Dada }\end{array}$} & \multirow[b]{2}{*}{ A0 } & 39,22 & 38,08 & 37,88 & 37,52 & 38,18 \\
\hline & & $\pm 0,34^{\mathrm{a}}$ & $\pm 0,34^{\mathrm{b}}$ & $\pm 0,32^{\mathrm{bc}}$ & $\pm 0,29^{\mathrm{bc}}$ & $\pm 0,74$ \\
\hline & \multirow{2}{*}{ A1 } & 38,85 & 38,81 & 38,54 & 37,43 & 38,41 \\
\hline & & $\pm 0,43^{\mathrm{ab}}$ & $\pm 0,37^{\mathrm{ab}}$ & $\pm 0,30^{\mathrm{ab}}$ & $\pm 0,35^{\mathrm{bc}}$ & $\pm 0,67$ \\
\hline & \multirow{2}{*}{ Rataan } & 39,04 & 38,45 & 38,21 & 37,47 & 38,29 \\
\hline & & $\pm 0,26$ & $\pm 0,52$ & $\pm 0,46$ & $\pm 0,06$ & $\pm 0,16$ \\
\hline \multirow{6}{*}{$\begin{array}{l}\text { Persentase } \\
\text { Paha Atas }\end{array}$} & \multirow{2}{*}{ A0 } & 14,34 & 14,67 & 14,53 & 14,32 & 14,47 \\
\hline & & $\pm 0,17$ & $\pm 0,19$ & $\pm 0,19$ & $\pm 0,19$ & $\pm 0,16$ \\
\hline & \multirow[b]{2}{*}{ A1 } & 14,67 & 14,63 & 14,58 & 14,64 & 14,63 \\
\hline & & $\pm 0,18$ & $\pm 0,22$ & $\pm 0,18$ & $\pm 0,18$ & $\pm 0,04$ \\
\hline & \multirow{2}{*}{ Rataan } & 14,52 & 14,65 & 14,56 & 14,48 & 14,55 \\
\hline & & $\pm 0,23$ & $\pm 0,03$ & $\pm 0,03$ & $\pm 0,23$ & $\pm 0,12$ \\
\hline \multirow{6}{*}{$\begin{array}{l}\text { Persentase } \\
\text { Paha Bawah }\end{array}$} & \multirow{2}{*}{ A0 } & 12,87 & 13,60 & 12,84 & 13,39 & 13,18 \\
\hline & & $\pm 0,33$ & $\pm 0,31$ & $\pm 0,37$ & $\pm 0,18$ & $\pm 0,38$ \\
\hline & \multirow{2}{*}{ A1 } & 13,34 & 13,18 & 12,92 & 13,43 & 13,22 \\
\hline & & $\pm 0,53$ & $\pm 0,42$ & $\pm 0,25$ & $\pm 0,18$ & $\pm 0,23$ \\
\hline & \multirow{2}{*}{ Rataan } & 13,11 & 13,39 & 12,88 & 13,41 & 13,20 \\
\hline & & $\pm 0,33$ & $\pm 0,30$ & $\pm 0,05$ & $\pm 0,03$ & $\pm 0,03$ \\
\hline & 10 & 19,31 & 18,50 & 18,68 & 19,44 & 18,98 \\
\hline & A0 & $\pm 0,15^{\mathrm{a}}$ & $\pm 0,14^{\mathrm{b}}$ & $\pm 0,11^{\mathrm{b}}$ & $\pm 0,12^{\mathrm{a}}$ & $\pm 0,46$ \\
\hline Persentase & $\mathbf{A 1}$ & 18,66 & 19,40 & 19,54 & 19,67 & 19,32 \\
\hline Punggung & A1 & $\pm 0,11^{\mathrm{b}}$ & $\pm 0,06^{\mathrm{a}}$ & $\pm 0,04^{\mathrm{a}}$ & $\pm 0,12^{\mathrm{a}}$ & $\pm 0,45$ \\
\hline & Rataan & 18,99 & 18,95 & 19,11 & 19,55 & 19,15 \\
\hline & Rataan & $\pm 0,46$ & $\pm 0,63$ & $\pm 0,61$ & $\pm 0,16$ & $\pm 0,24$ \\
\hline & & 9,38 & 9,35 & 8,73 & 9,35 & 9,20 \\
\hline & A0 & $\pm 0,15$ & $\pm 0,11$ & $\pm 0,11$ & $\pm 0,14$ & $\pm 0,32$ \\
\hline Persentase & $\mathbf{A 1}$ & 9,59 & 9,47 & 9,33 & 9,57 & 9,49 \\
\hline Sayap & A1 & $\pm 0,18$ & $\pm 0,22$ & $\pm 0,12$ & $\pm 0,19$ & $\pm 0,12$ \\
\hline & Rataan & 9,49 & 9,41 & 9,03 & 9,46 & 9,35 \\
\hline & Kataan & $\pm 0,15$ & $\pm 0,09$ & $\pm 0,43$ & $\pm 0,15$ & $\pm 0,20$ \\
\hline
\end{tabular}

Ket: Superskrip berbeda pada baris dan kolom menunjukkan perbedaan yang nyata $(\mathrm{P}<0,05)$.

Pengaruh Perlakuan terhadap Bobot Karkas
Data rataan bobot karkas ayam broiler dapat dilihat pada Tabel 3. Rataan 
bobot karkas berkisar antara 1746,00 2232,00 gram/ekor. Hasil penelitian ini lebih tinggi dibandingkan dengan penelitian yang dilakukan oleh Fitria et al. (2014) pada penelitian penambahan tepung kulit manggis terhadap pertumbuhan dan produksi karkas ayam broiler strain Lohman dengan bobot karkas sebesar 1080 sampai 1105 gram. Anova menunjukkan bahwa interaksi antara kombinasi perlakuan pembatasan pakan dan pemberian sumber serat kasar memberikan pengaruh yang berbeda nyata $(\mathrm{P}<0,05)$ terhadap bobot karkas ayam broiler. Uji BNJ menunjukkan bahwa bobot karkas A0B3 sama dengan A0B0, namun berbeda nyata $(\mathrm{P}<0,05)$ dengan A0B2, A1B3, A1B2, A1B0, A0B1, A1B1. A0B0 sama dengan A0B2 namun berbeda nyata $(\mathrm{P}<0,05)$ dengan A1B3, A1B2, A1B0, A0B1, A1B1 terhadap bobot karkas. A0B2 sama dengan A1B3 namun berbeda nyata $(\mathrm{P}<0,5)$ dengan pembatasan $20 \%$ dan pakan komersial dengan dedak padi A1B2, A1B0, A0B1, A1B1 terhadap bobot karkas. A0B2 berbeda nyata $(\mathrm{P}<0,05)$ dengan $\mathrm{A} 1 \mathrm{~B} 0$, A0B1, A1B1 terhadap bobot karkas.

Strain dapat mempengaruhi bobot karkas, dimana strain yang memiliki bobot potong yang besar akan menghasilkan bobot karkas yang besar (Berg \& Butterfield, 1976). Tandi (2010) menyatakan bahwa dalam kulit kopi terdapat zat anti nutrisi berupa tannin.
Yamin (2010) menyatakan bahwa galaktomanan adalah polisakarida yang terdiri dari rantai mannose dan galaktosa yang bermanfaat bagi kesehatan karena menggandung serat dan polisakarida, juga berperan memicu pertumbuhan bakteri usus yang membantu perncernaan.

\section{Pengaruh Perlakuan terhadap Persentase Dada}

Rataan persentase dada pada penelitian ini berkisar antara $37,43 \%$ sampai 39,22\% (Tabel 3). Tatli et al., (2007) menyatakan bahwa persentase dada yang baik pada ayam lebih dari 35\% dari bobot karkas. Persentase dada dalam penelitian ini lebih tinggi dibandingkan dengan Banong \& Hakim (2011) yang menyatakan bahwa persentase dada pada ayam broler umur 5 minggu yang mengalami pemuasaan sebesar $29,4 \%$ sampai 30,3\%. Hasil analisis keragaman menunjukkan bahwa interaksi antara perlakuan pembatasan pakan dan sumber serat memberikan pengaruh nyata $(\mathrm{P}<0,05)$ terhadap persentase dada. Uji beda nyata jujur (BNJ) menunjukkan bahwa persentase dada ayam broiler yang mendapatkan kombinasi perlakuan A0B0 sama dengan A1B0, A1B1 dan A1B2, namun berbeda nyata $(\mathrm{P}<0,05)$ dengan $\mathrm{A} 0 \mathrm{~B} 1, \mathrm{~A} 0 \mathrm{~B} 2$, A0B3, A1B3. Begitu juga dengan ayam broiler yang mendapatkan kombinasi perlakuan A1B0 tidak berbeda nyata 
dibandingkan dengan A1B1, A1B2, A0B1, A0B2, namun berbeda nyata $(\mathrm{P}<0,05)$ dengan A0B3, A1B3 terhadap persentase dada. Kombinasi perlakuan A0B2, A0B3 dan A1B3 memberikan pengaruh yang sama terhadap persentase dada.

Komponen karkas yang paling mahal adalah daging. Bagian daging terbesar terdapat pada bagian dada, sehingga besarnya dada dijadikan ukuran untuk memperbandingkan kualitas daging pada ternak (Londok \& Rompis, 2018). Perkembangan daging pada bagian dada juga dipengaruhi oleh umur dan genetik, dimana ayam broiler yang berukuran besar akan menghasilkan bobot atau persentase dada yang besar pula. Santoso, (2003) menyatakan bahwa pembatasan pakan dapat meningkatkan berat badan, menurunkan konversi pakan, meningkatkan efisiensi penggunaan pakan dan menurunkan deposisi lemak pada broiler.

\section{Pengaruh Perlakuan terhadap Persentase Paha Atas}

Hasil penelitian ini menunjukkan bahwa rataan persentase paha atas berkisar antara $14,32 \%$ sampai $14,67 \%$ (Tabel 3). Penelitian ini lebih tinggi dibandingkan dengan yang direkomendasikan untuk ayam broiler strain Lohman yang berumur 6 minggu dengan bobot badan 2,6kg, persentase paha atas sebesar 13,22\%
(Lohman Meat, 2007). Anova menunjukkan bahwa interaksi antara perlakuan pembatasan pakan dan sumber serat memberikan pengaruh yang tidak nyata $(\mathrm{P}>0,05)$ terhadap persentase paha atas ayam broiler. Namun pada perlakuan pembatasan pakan memberikan pengaruh yang nyata $(\mathrm{P}<0,05)$ terhadap persentase paha atas ayam broiler.

Paha atas merupakan bagian karkas yang menghasilkan daging kedua terbanyak setelah dada, perkembangannya dipengaruhi oleh kandungan protein dalam pakan (Resnawati, 2004). Tinggi rendahnya proporsi daging dipengaruhi oleh besaran bobot hidup akhir ternak (Fawwad et al., 2006). Pembatasan pakan tidak mempunyai dampak buruk terhadap karakteristik karkas yang dihasilkan, namun diharapkan dapat meningkatkan produksi karkas (Immamudin et al., 2012).

\section{Pengaruh perlakuan terhadap persentase paha bawah}

Rataan persentase paha bawah (Tabel 3) berkisar antara $12,84 \%$ sampai 13,60\%. Hasil ini masih berada pada kisaran normal dari yang direkomendasikan oleh Lesson dan Summers (1997) menyatakan bahwa persentase paha bawah pada ayam broiler yang berumur 6 minggu sebesar $13,01 \%$ dan lebih tinggi dibandingkan dengan yang direkomendasikan untuk ayam broiler 
strain Lohman dengan bobot badan $2,6 \mathrm{~kg}$ persentase paha bawahnya sebesar $9,63 \%$ (Lohman Meat, 2007). Hasil analisis keragaman interaksi antara perlakuan pembatasan $20 \%$ dan sumber serat memberikan pengaruh tidak nyata $(\mathrm{P}>0,05)$ terhadap persentase paha bawah, akan tetapi perlakuan sumber serat (B) memberikan pengaruh yang nyata $(\mathrm{P}<0,05)$ terhadap persentase paha bawah. ayam broiler yang mendapatkan perlakuan B3 tebih tinggi $(\mathrm{P}<0,05)$ dibandingkan dengan B0, B1 dan B2.

Paha bawah merupakan salah satu potongan karkas yam broiler yang terdiri dari perdagingan dan pertulangan serta merupakan alat gerak (Ramdani et al., 2016). Massolo et al. (2016) menyatakan bahwa kecilnya deposit daging pada bagian-bagian karkas dipengaruhi oleh besarnya persentase tulang, persentase paha bawah juga ditentukan oleh besarnya bobot karkas dan bagian-bagian karkas lainnya.

\section{Pengaruh Perlakuan terhadap Persentase Sayap}

Penelitian ini menunjukkan bahwa rataan persentase sayap berkisar antara 8,73\% sampai 9,59\% (Tabel 3). Persentase sayap dalam penelitian ini lebih rendah dari yang direkomendasikan oleh Grata et al. (2017) dan Toplu et al. (2014). Grata et al. (2017) menyatakan bahwa persentase sayap ayam broiler yang mengalami pebatasan pakan berkisar antara 9,5\% sampai $9,7 \&$ 12,70-13,20, dan Toplu et al. (2014) persentase sayap broiler berkisar antara 11,03 sampai11,92\%. Hasil analisis keragaman menunjukkan bahwa interaksi antara kombinasi perlakuan pembatasan pakan dan sumber serat kasar memberikan pengaruh yang tidak nyata $(\mathrm{P}>0,05)$ terhadap persentase sayap. Meskipun antara kedua kombinasi perlakuan tersebut tidak memberikan interaksi, namun masing-masing perlakuan pembatasan pakan (A) dan perlakuan sumber serat kasar bahan pakan (B) memberikan pengaruh yang nyata $(\mathrm{P}<0,05)$ terhadap persentase sayap. Untuk perlakuan pembatasan, perlakuan A1 nyata lebih tinggi dibandingkan dengan A0. Persentase sayap ayam broiler yang mendapatkan perlakuan B0 nyata lebih tinggi dibandingkan dengan perlakuan B3, demikian halnya dengan B1 dan B3 nyata lebih tinggi dibandingkan dengan B2, tetapi lebih rendah dari B0.

Sayap adalah bagian karkas yang terdiri atas pertulangan dan terdapat banyak bulu, hal tersebut yang menyebabkan persentase sayap lebih rendah dibandingkan dengan bagian lainnya. Massolo et al. (2016) menyatakan bahwa kecilnya deposit daging pada bagian-bagian karkas dipengaruhi oleh besarnya persentase tulang. 


\section{Pengaruh Perlakuan terhadap Persentase Punggung}

Berdasarkan hasil penelitian nilai rataan persentase punggung (Tabel 3) berkisar antara 18,50 - 19,67\% dari persentase karkas. Hasil ini lebih rendah dibandingkan dengan penelitian yang telah dilakukan oleh Londok dan Rompis (2008) menyatakan bahwa persentase punggung 2 strain ayam pedaging umur 5 minggu berkisar 19,59-20,35\%, namun lebih tinggi dibandingkan dengan Marzani et al. (2016) persentase punggung umur 5 minggu berkisar antara 8,96-10,45\%. Hasil analisis keragaman menunjukkan bahwa interaksi antara perlakuan pembatasan pakan dan pemberian sumber serat kasar berbeda memberikan pengaruh yang nyata $(\mathrm{P}<0,05)$ terhadap persentase punggung ayam broiler. Hasil uji BNJ menunjukkan bahwa persentase punggung ayam broiler yang mendapatkan perlakuan A1B3 tidak berbeda nyata dengan A1B2, A0B3, A1B1 dan A0B0, namun berbeda nyata $(\mathrm{P}<0,05)$ dengan A0B2, A1B0 dan A0B1. Kombinasi perlakuan A0B2, A1B0 dan A0B1 memberikan pengaruh yang sama terhadap persentase punggung.

Persentase punggung tersusun atas sebagian besar kerangka tulang dan sedikit jaringan otot. Resnawati (2004) menyatakan bahwa punggung ayam pedaging sebagian besar tersusun atas jaringan tulang dan sedikit jaringan otot, sehingga kandungan mineral dalam pakan lebih berpengaruh terhadap bobot punggung.

\section{KESIMPULAN}

Pembatasan pakan 20\% dengan ampas kelapa sebagai pakan sumber serat kasar memberikan hasil yang baik terhadap bobot hidup, bobot karkas dan potongan komersial ayam broiler strain Lohman.

\section{UCAPAN TERIMA KASIH}

Ucapan terima kasih disampaikan kepada Pemerintah Republik Indonesia Kementrian Riset Teknologi dan Pendidikan Tinggi, sebagai penyandang dana penelitian dengan nomor kontrak 087/SP2H/LT/DRTM/2018.

\section{DAFTAR PUSTAKA}

Akmal dan Filawati. 2008. Pemanfaatan kapang Aspergillus niger sebagai inokulan fermentasi kulit kopi dengan media cair dan pengaruhnya terhadap performans ayam broiler. Jurnal Ilmu-Ilmu Peternakan. 11(3).

Banong, S. dan M.R. Hakim. 2011. Pengaruh umur dan pemuasaan terhadap performans dan karakteristik karkas ayam pedaging. Jurnal Ilmu Dan Ternologi Peternakan 1(2). 
Berg, R.T dan R.M. Butterfield. 1976. New Conceptsof Cattle Growth. Sydney. Sydney University Press.

Fawwad, A., S. Mahmood, Z.U. Rehman, M. Ashraf, M. Alam dan A. Muzaffar. 2006. Effect of feeding management on energy, protein intake and carcass characteristics of broiler during summer. Int. J. of Agric and Biol. 8:546-549.

Fitria, S., S. Maharani, Supadmo dan Zuprizal. 2014. Pengaruh penambahan tepung kulit manggis (Garcinia Mangostana L) sebagai aditif pakan terhadap pertumbuhan dan produksi karkas ayam broiler. Jurnal Buletin Peternakan 38(2): 8389.

Gratta, F., M. Birolo, G. Xiccato dan A. Trocino. 2017. Effect of genotype, gender and feed restriction on slaughter result and meat quality of broiler chickens. Agriculture Conspectus Scientificus 82(3): 311314.

Immamudin, U. Atmomarsono, M.H. Nasution. 2012. Pengaruh berbagai frekuensi pemberian pakan pada pembatasan pakan terhadap produksi karkas ayam broiler broiler. Animal Agricultural Journal 1(1) : 87-98.

Kusuma, H.A., A. Mukhtar dan R. Dewanti. 2016. Pengaruh tingkat pembatasan pakan (Restricted Feeding) terhadap performan ayam broiler jantan. Sains Peternakan 14(1) 43-51

Kusriningrum, R. S. 2010. Perancangan Percobaan. Pusat Penerbit dan Percetakan Unair (AUP). Surabaya.

Leeson, S., dan J.D. Summers. 1997. Commercial Poultry Nutrition. $2^{\text {nd }}$. University Books. University of Guelph. Canada.
Lohman Meat. 2007. Pedaging Stock Performans Objektives. Albama (US): Aviagen.

Londok, J.J.M.R., B. Tulung, Y.H.S. Kowel dan J.E.G. Rompis. 2012. Effect of feed restriction on feed efficiency, carcas quality and digestive organs charactheristics of broiler. Proceeding The $2^{\text {nd }}$ International Seminar "Feed Safety For Healty Food". AINI And Faculty of Animal Husbandry, Universitas Pajajaran Jatinangor.

Londok, J.J.M.R dan Rompis J.E.G. 2018. Pengaruh pembatasan pakan pada periode starter terhadap potongan komersial 2 strain ayam pedaging. Seminar Nasional VII HITPI, Fakultas Pertanian UNISKA. Banjarmasin.

Londok, J.J.M.R. 2018. Produksi Daging Ayam broiler Fungsional Tinggi Asam Laurat Dan Antioksidan Alami Melalui Penggunaan Minyak Dan Area Vestiaria Giseke. Disertasi. Program Pascasarjana, IPB. Bogor.

Londok, J.J.M.R., R.A.V. Tuturoong dan J.E.G. Rompis. 2018. Pengaruh pembatasan pakan (Feed Restriction) terhadap performa dua strain ayam broiler periode starter. Laporan Akhir Riset Terapan Unggul Unsrat. Manado.

Mahmood, S., S. Mehmood, F. Ahmad, A. Masood dan R. Kausar. 2007. Effect of feed restriction during starter phase on subsquent growth performance, dressing percentage, relative organ weights and immune response of broiler. Pakistan J. Vet. 27(3):137141.

Markley, S.W., G.W. Weinland, Malone dan G.W. Chaloupka. 1980. 
Evaluation of five commercial broiler crosses 2. Eviscerated yield and component parts. J. Poult. Sci. 59: 1755-1760.

Marzani, R., Samadi dan Herawati. 2016. Pengaruh substitusi amtabis yang difermentasi dengan Aspergillus Niger terhadap berat dan persentase karkas broiler. Jurnal Ilmiah Mahasiswa Pertanian Unsyiah 1(1).

Massolo, R., A. Mujnis dan L. Agustina. 2016. Persentase karkas dan lemak abdominal broiler yang diberi prebiotic inulin umbi bunga dahlia (Dahlia Variaillis). Jurnal Bulletin Nutrisi dan Makanan Ternak 12(2): 50-58.

Novita. 2012. Penggunaan ampas kelapa (Cocos Nucifera L) fermentasi sebagai pakan ayam broiler pedaging terhadap berat badan dan penurunan kadar kolesterol darah. ilmutaniternak.blogspot.com/2013/11/pe nggunaan-ampas-kelapa-cocosnucifera.html (01 mei 2018).

Nugraheni, M. 2013. Pengetahuan Bahan Pangan Hewani. Edisi I. Graha Ilmu. Yogyakarta.Purawisastra, S. 2001. Pengaruh Isolat galaktomanan kelapa terhadap penurunan kadar kolesterol serum kelinci. Center for Research and Develovment of Nutrition and Food NIHRD. Badan Litbang Kesehatan. Jakarta.

Ramdani, I., D. Kardaya dan Anggraeni. 2016. Pengaruh substitusi pakan komersial dengan tepung ampas kelapa terhadap bobot potong dan bobot karkas ayam kampung. Jurnal Peternakan Nusantara 2(1).

Resnawati, H. 2004. Bobot potong karkas, lemak abdomen daging dada ayam pedaging yang diberi ransum menggunakan tepung cacing tanah
(Lumbricus Rubellus). Seminar Nasional Teknologi Peternakan dan Veteriner. Balai Penelitian Ternak. Bogor.

Santoso, U. 2003. The Beneficial Effect of Early Feed Restriction on Growth, Body Composition and Fat Accumulation in Broiler Chickens: a Review. J. Indon. Trp. Anim. Agric. 28(1): 39-48.

Tandi, E.J. 2010. Pengaruh tanin terhadap aktivitas protease. Seminar nasional teknologi peternakan dan veteriner. Fakultas peternakan. Universitas Hasanuddin. Makassar. Hal: 567570.

Tatli, P., I. Seven, M. Yilmaz, U.G. Simsek. 2007. The effect of turkish propolis on growth and carcass characteristics in broiler under heat stress. Anim Feed Sci Technol. 146: 137-148.

Toplu, D.O., A. Nazligul A, S. Karaarslan, M. Kaya dan O. Yagin. 2014. Effects of head conditioning and dietary ascorbic acid supplementation on growth performance, carcass and meat quality characteristics in heatstressed broilers. Ankara Unive Vet Derg 61(295-302). Terkey.

Tulung, B., J.J.M.R. Londok dan M.R. Regar. 2015. The Effect length of feeding and level crude fiber carcass qualiti and serum cholesterol of broiler chiken. Proceding the 4nd Internasional of AINI. AINI and Faculty of Animal Husbandry, Sam Ratulangi University. Manado.

Yamin, M. 2008. Pemanfaatan ampas kelapa dan ampas kelapa fermentasi dalam ransum terhadap efisiensi ransum dan income over feed cost ayam pedaging. Jurnal Agroland 15(2): 135-139. 